\title{
Aquatic Training with Play Methods in Improving Swimming Skills in Preschool Children
}

\author{
Sandra Arhesa*, Dewi Laelatul Badriah \\ Physical Education Study Program, Faculty of Teacher Training and Education, Universitas Majalengka, Majalengka, Indonesia
}

Received April 23, 2021; Revised July 14, 2021; Accepted July 22, 2021

\section{Cite This Paper in the following Citation Styles}

(a): [1] Sandra Arhesa, Dewi Laelatul Badriah, "Aquatic Training with Play Methods in Improving Swimming Skills in Preschool Children," International Journal of Human Movement and Sports Sciences, Vol. 9, No. 4A, pp. 106 - 111, 2021. DOI: 10.13189/saj.2021.091318.

(b): Sandra Arhesa, Dewi Laelatul Badriah (2021). Aquatic Training with Play Methods in Improving Swimming Skills in Preschool Children. International Journal of Human Movement and Sports Sciences, 9(4A), 106 - 111. DOI: 10.13189/saj.2021.091318.

Copyright $\odot 2021$ by authors, all rights reserved. Authors agree that this article remains permanently open access under the terms of the Creative Commons Attribution License 4.0 International License

\begin{abstract}
This study aimed to determine the increase of swimming skills in aquatic training by playing methods for preschool children. The research method used was pre-experimental with a one-shot case study design. The populations were forty swimming participants at the Arhesa Swimming Club. Thirteen preschool children aged four to six years old (five males and eight females) were involved in the study. The research instrument were swimming skills test for preschool children's with water recognition indicators, pool entry, breath control, float, arms push, leg movement, and complete swimming. Data were analyzed using descriptive statistics. The results showed that six children were in a good category with a percentage of forty-six point fifteen, four children were in a moderate category with a percentage of thirty point seven six, and three children were in a low category with a percentage of twenty-three point zero seven. It concludes that aquatic training with the play method can improve swimming skills of pre-school children. It is suggested for further research to use other experimental methods, with a large sample, and increase the number of meetings.
\end{abstract}

Keywords Aquatic Training, Playing Method, Swimming Skill, Preschool Children

\section{Introduction}

Preschool age is important for the children growth and development. It is marked by the rapid development of children intelligence and motor skills. This phase includes the right time to introduce children to water activities and teach basic swimming skills. According to Susanto [1], the age of 4 to 6 years old is an important growth and development age to introduce basic swimming skills. Swimming could be introduced to children ideally between the ages of 3 and 7 years old [2] or at the ages of 3.5 and 5 years [3]. In Indonesia, the early childhood limit is between 3-6 years old, so it is called preschool children [4]. Children at the age of 3 have an average height of about $80-90 \mathrm{~cm}$, weight between $10-13 \mathrm{~kg}$. At the age of 5, the height has reached about $100-110 \mathrm{~cm}$ because the leg bones grow rapidly and get bigger and stronger. Brain growth reaches $75 \%$ of adult size and $90 \%$ by age of 6 years. At this age, the physiological changes are seen from slower and deeper breathing and a slower and persistent heart rate. The physical development of children is marked by changes in motor skills, both gross and fine motor skills. Researchers have studied the motor development and swimming skills of children. Erbaugh [3] describes the development of swimming during infancy. He observed that there are three phases of swimming in babies: reflexive, irregular, and voluntary. Each phase has unique movement characteristics associated with the fundamental development of the central nervous system. Physically, the child will be successful in swimming after the muscle and nerve fibers are mature. Therefore, having a child who starts swimming at an early age does not necessarily mean that they are better at swimming skills or 
have better swimming quality than those who started at an older age.

Swimming is a sport that involves the large and small muscles. It can help accelerate growth and development physically and intellectually which is in great demand by various groups from children to the elderly. By swimming, children have the opportunity to know and understand their environment. Through swimming, children have the opportunity to move freely, and under any circumstances, they must move all their limbs to be able to float and move. This flexibility is a tremendous stimulus, not only from the physical aspect but also from the mental aspect [5]. Swimming is a valuable skill for children. Apart from helping them stay safe, it is also a form of multipurpose exercise that is relaxing, fun, that can be done at any time and becomes a therapeutic activity to produce regular movements [6]. Before mastering regular movements, children must first master the basic swimming skills by taking aquatic training.

Aquatic training is all activities or media that are carried out in the water or in the swimming pools to train children to improve their motor, cognition, affection, and social potential. Swimming is one of the aquatic trainings. According to Susanto [1], basic motor skills in swimming consist of seven components: water orientation, water entry, breath control, buoyancy, arm propulsion, leg action, and combined movement. In his research, Erbaugh [3] found six special characteristics of swimming that can increase the body significantly, for example, arm movements, leg movements, body position, head position, distance travelled, and independence. Getz et al [7] argue that aquatic exercises cover water adjustment skills, longitudinal, rotation, sagittal rotation, and swimming skills. According to Lim and Yoon [8], aquatic exercises consist of side walking and running, walking and running forward, stepping across, and ambushing. The exercises include activities that are focused on joint mobility, flexor and extensor muscle strength, balance, movement, posture, functional activities, intermittent walking, and lower leg muscle strength $[9,10]$.

The success of aquatic exercise programs for preschoolers depends on several factors, such as age, physical characteristics, language and cognitive development, level of socialization, and emotional factors. Age and gender are also factors that influence swimming skills [3]. Meanwhile, risk factors, anxiety, and fear are more inhibiting to swimming than other factors, such as facilities, infrastructure, and the environment [11]. The indicators of training success lie in the skill mastered and the benefits for preschool children. Swimming skills in preschool children cannot be separated from the development of children potential through three domains, including basic psychomotor skills, basic attitude, and basic understanding. A good training process is carried out intensively, consistently, and continuously which does not cause boredom in children. According to Anista et al.
[12], aquatic exercises are also beneficial for musculoskeletal health and improve neuromuscular and functional fitness performance [13,14]. It can be applied to children to improve fitness and body functions because the nature of water reduces excessive joint load and increases strengthening to assist children for posture and muscle control.

The study of Katsura et al [15] shows that water sport training could be carried out for 90 minutes, three times a week for 8 weeks in a small pond with water temperatures ranging from $30-32^{\circ} \mathrm{C}$. The 90 minutes consist of warming up 15 minutes of walking and flexibility training, 60 minutes of endurance, strength training, and 15 minutes of cool down. Erbaugh [3] suggests that aquatic exercise during infancy and early childhood significantly affects swimming quality and swimming skills and promotes positive attitudes about swimming. According to studies, aquatic exercise can also increase body composition, physical capacity [16], and motor performance [17]. Meanwhile, swimming training is highly recommended for children and adolescents, especially those who have asthma because it will have an impact on cardiopulmonary fitness and lung function [18]. Seeing the results and research procedures above, a trainer must be good at choosing and providing training methods for children aimed to improve technique mastery in a swimming material to be studied. This effort can be done through swimming training with the playing method.

\section{Method}

This research used a pre-experimental study, with a one-shot case study research design. It is the simplest research design because it only includes one group, without a control group. The experimental group did not have a pretest but were given aquatic training treatment with the play method and a posttest using the preschool children swimming skill test. The study population was all swimming participants at the Arhesa swimming club with a total of 40 participants consisting of 23 boys and 17 girls, from preschoolers to university students. The sample was selected based on the purposive sampling technique, including 13 preschool children aged 4-6 years (5 boys and 8 girls). The research instrument was in the form of a preschool children swimming skill test. The indicators included water recognition, pool entry, breath control, float, arm push, leg movement, and complete swimming adapted from Susanto [1] (see Table 1).

Data were collected after the samples received aquatic training treatments, such as water recognition, entering the pool, breathing control, floats, arm push, leg movement, and complete swimming using playing methods in the form of running competitions, water cats and fish, taking coins, driving away from the poison, blowing an object, diving, and pulling a buoy. The data were collected for three months, from July to September 2020, with three 
meetings every week. A total of 36 meetings were held for 40 minutes: 10 minutes of warming up on land and in the water, 25 minutes of aquatic training with the playing method, and 5 minutes of cooling down after the treatment. The samples were given a swimming skill test which was carried out by four assessors, including two trainers as the persons who gave aquatic training. According to the treatment time, 1 trainer trained 7 children and another 1 trainer trained 6 children. The other 2 assessors became observation recorders by filling in the provided checklist to indicate the skill level obtained. The scores were added up from the 7 assessed aspects so that a maximum score
(30) and a minimum score (7) appeared, thus a range of scores gained in good, medium, and poor categories. The data were then processed using descriptive statistical analysis in the form of percentages. The mean, min, max, and standard deviation were also calculated.

\section{Results}

Data were analyzed using descriptive statistics so that the percentage of the seven aspects assessed could be found from the 13 research samples.

Table 1. Test Instruments for Preschool Children Swimming Skills

\begin{tabular}{|c|c|c|}
\hline Level & RATED ASPECT & \multirow{2}{*}{$(\sqrt{ })$} \\
\hline & WATER INTRODUCTION & \\
\hline \multirow[t]{2}{*}{$1-3$} & $\begin{array}{l}\text { (1) Do not want to get into the pool or are afraid of water, (2) voluntarily get into the pool but the level of } \\
\text { fear of water is less, and (3) willing to get into the pool without fear }\end{array}$ & \\
\hline & ENTER IN THE POOL & \\
\hline \multirow[t]{2}{*}{$1-5$} & $\begin{array}{l}\text { (1) Do not want to get into the pool, (2) with examples, entering feet first, (3) without examples, entering } \\
\text { feet first, (4) with examples, entering face first, (5) without examples, entering face first }\end{array}$ & \\
\hline & BREATHING CONTROL & \\
\hline \multirow[t]{2}{*}{$1-5$} & $\begin{array}{l}\text { (1) Breathing with the help of a handle, (2) breathing with the blowing air movement, (3) breathing by } \\
\text { entering the face to the nose into the water, (4) doing inhale repetitions, (5) breathing movement with the } \\
\text { whole face into the water with simple swimming movements }\end{array}$ & \\
\hline & FLOAT & \\
\hline \multirow[t]{2}{*}{$1-4$} & $\begin{array}{l}\text { (1) Does not float, (2) floats with the assistance of a companion, (3) floats with commands/instructions, } \\
\text { (4) floats without commands/ instructions }\end{array}$ & \\
\hline & ARM MOVEMENT & \\
\hline \multirow[t]{2}{*}{$1-4$} & $\begin{array}{l}\text { (1) There is no arm movement yet, (2) the downward arm movement is still weak, (3) the pull and push } \\
\text { movements are not full yet, (4) the arm movement and forward movement are visible }\end{array}$ & \\
\hline & FOOT MOVEMENTS & \\
\hline \multirow[t]{2}{*}{$1-4$} & $\begin{array}{l}\text { (1) Leg movements have not appeared yet, (2) foot movements are still like pedalling a bicycle, (3) leg } \\
\text { movements are correct but not regular, (4) leg movements are correct }\end{array}$ & \\
\hline & COMBINATION MOVEMENT (FULL SWIMMING) & \\
\hline $1-5$ & $\begin{array}{l}\text { (1) Irregular combination movements, (2) combined movements but inconsistent, (3) combined } \\
\text { movements but less effective, (4) combined movements with short distances, (5) combined movements } \\
\text { with long and effective distances }\end{array}$ & \\
\hline
\end{tabular}

Table 2. Results of swimming skill tests

\begin{tabular}{|c|c|c|c|c|c|c|c|c|}
\hline \multirow[b]{2}{*}{ Name } & \multicolumn{7}{|c|}{ Rated aspect } & \multirow[b]{2}{*}{ Total } \\
\hline & $\begin{array}{c}\text { Water } \\
\text { introduction }\end{array}$ & $\begin{array}{c}\text { Entering the } \\
\text { pool }\end{array}$ & $\begin{array}{c}\text { Breathing } \\
\text { control }\end{array}$ & Float & $\begin{array}{c}\text { Arm } \\
\text { movement }\end{array}$ & $\begin{array}{c}\text { Foot } \\
\text { Movement }\end{array}$ & $\begin{array}{c}\text { Combination } \\
\text { Movement }\end{array}$ & \\
\hline 1 & 3 & 5 & 5 & 3 & 4 & 4 & 4 & 28 \\
\hline 2 & 2 & 4 & 2 & 2 & 1 & 2 & 1 & 14 \\
\hline 3 & 2 & 4 & 1 & 2 & 2 & 2 & 1 & 14 \\
\hline 4 & 3 & 5 & 5 & 2 & 2 & 3 & 1 & 21 \\
\hline 5 & 3 & 5 & 4 & 2 & 3 & 3 & 2 & 22 \\
\hline 6 & 3 & 5 & 5 & 3 & 4 & 3 & 4 & 27 \\
\hline 7 & 3 & 5 & 5 & 4 & 4 & 4 & 5 & 30 \\
\hline 8 & 3 & 5 & 5 & 3 & 4 & 3 & 4 & 27 \\
\hline 9 & 3 & 5 & 4 & 3 & 1 & 2 & 1 & 19 \\
\hline 10 & 3 & 5 & 5 & 3 & 4 & 3 & 2 & 25 \\
\hline 11 & 3 & 4 & 5 & 3 & 3 & 3 & 4 & 25 \\
\hline 12 & 2 & 4 & 4 & 2 & 1 & 4 & 1 & 18 \\
\hline 13 & 2 & 3 & 1 & 2 & 1 & 2 & 1 & 12 \\
\hline \multicolumn{8}{|c|}{ Total } & 282 \\
\hline
\end{tabular}


Table 2 explains that 7 aspects were assessed with the level of assessment for each aspect varying from the lowest score to the highest. The mean and standard deviation as well as the minimum and maximum scores can be seen in Table 3 .

Table 3. Descriptive Statistics

\begin{tabular}{|c|c|c|c|c|c|}
\hline Aspect & N & Min & Max & Mean & $\begin{array}{c}\text { Std. } \\
\text { Deviation }\end{array}$ \\
\hline $\begin{array}{c}\text { Preschool } \\
\text { Swimming Skill } \\
\text { Test }\end{array}$ & 13 & 12 & 30 & 21.69 & 5.92 \\
\hline
\end{tabular}

Table 3 describes the swimming skill test of 13 preschool children as the samples. The minimum score was 12 . The maximum score was 30. The mean was 21.69. The standard deviation was 5.92. Based on the results of these calculations, the class interval score was obtained for determining the swimming skill category of preschool children. The range of scores for determining the category is shown in Table 4.

Table 4. Value, Score Range, Category, and Percentage

\begin{tabular}{|c|c|c|c|c|}
\hline Aspect & $\begin{array}{c}\text { Score } \\
\text { Range }\end{array}$ & Category & Children & Percentage \\
\hline Preschool & $23-30$ & Good & 6 & 45.15 \\
\cline { 2 - 5 } $\begin{array}{c}\text { Swimming } \\
\text { Skill Tests }\end{array}$ & $15-22$ & Moderate & 4 & 30.76 \\
\cline { 2 - 5 } & $7-14$ & Less & 3 & 23.07 \\
\hline
\end{tabular}

In Table 4, the score ranges include good category ranging from 23 to 30 , moderate category ranging from 15 to 22 , and the poor category ranging from 7 to 14 . For swimming skills, the good category included 6 children $(46.15 \%)$, the moderate category included 4 children (30.76), and the less category included 3 children $(23.07 \%)$.

\section{Discussion}

From the above calculations, it is explained that 7 aspects were assessed, namely 3 levels of the water introduction, 5 levels of swimming, 5 levels of breath control, 4 levels of floating, 4 levels of arm push, 4 levels of leg movement, and 5 levels of complete swimming according to the skill test developed by Susanto [1]. This test aims to develop the motor skills, attitudes, and understanding of pre-school children. Swimming skill tests were carried out on 13 preschool children in the Arhesa swimming Club, with a minimum score of 12 , a maximum of 30 , an average of 21.69 , and a standard deviation of 5.92. Based on the results of these calculations, a class interval score was obtained for determining the swimming skill category of preschool children. The range of scores for determining the category ranges from good categories ranging from 23 to 30 , moderate categories ranging from 15 to 22 , and less category ranging from 7 to 14 . The percentage showed that $46.15 \%$ (6 children) were in the good swimming skill category, $30.76 \%$ (4 children) were in the moderate category, and $23.07 \%$ ( 3 children) in the less category.

From the results of the analysis of experts, the age of pre-school children is different. Erbaugh [3], in his research, took the age of 3.5-5 years to start swimming skills. The preschool children range from 3-6 years old [4], 4-6 years [1], 5-7 years [5]. The start of a post-infancy training program is at the age of 3-7 years [2]. An organized program is recommended for those aged under 3 years. Therefore, researchers took 4-6 years of age because the minimum age for those who exercise in Arhesa SC was 4 years old. Most of those who belonged to the good category were children aged 6 years compared to children aged 4 and 5 years. This is because the growth and development of 6-year-olds are more perfect so that the trainer tends to ask more questions and they do what is instructed. Children aged 5 years have more activities, tend to be more aggressive, and act on their own. These results indicate that the children still do not fully understand the instructions given. When given training, they still like to joke with their friends. This is in accordance with Wahyudi [5], that in the growth and development, children aged 5 years are in a period when children seek their own identity. For the poor category, in providing information related to swimming training to the children aged 4 years, the trainers must provide a lot of instructions until the child understands what to do and must be patient with it.

In the implementation of swimming skill tests for pre-school children, 7 assessed aspects, namely the introduction of water to complete swimming, can be analyzed one by one. At the introduction of water, the average of children wanted to enter the pool without fear. There were only 4 people who entered the pool with a little fear. When entering the pool, the child has the courage to enter his face first. There was one child who only dared to put his feet in. His breath control also had the whole face into the water with simple swimming movements. Two people were still afraid to breathe, that only could be done when there was a handle. Then, most of the floats were waiting for the trainer instructions first. There was only one child who could float well without instructions. For most of the arm movements, there were already visible arm movements and forward movements. There were 4 children whose arm movements had not yet appeared. Then, the leg movements were correct but not yet regular. There were 4 children whose leg movements were correct and most of the combination movements were irregular. There were 4 children whose combination movements were good but could only be done at a short distance. One person could do about $15 \mathrm{~m}$ distance. This is in line with the study conducted by Arhesa et al. [6] showing that doing movements must be regular from the easiest to the most difficult because swimming skills require a person to move their hands and feet so that they 
can float and move from one place to another and move the feet and hands continuously until reaching the finish.

Based on the description of the swimming skills test for preschool children, there were still children who were a little afraid to enter the pool and only dared to put their feet in before there was an instruction from the coach. It was because there were several factors that could hinder swimming skills. In accordance with the opinion of Erbaugh [3], age and gender are also factors that influence swimming skills. Arhesa et al [11] suggest that risk factors, anxiety, and fear are more inhibiting factors than other factors, such as facilities, infrastructure, and the environment.

Aquatic training includes playing methods. According to Engelhart and Aiken [19] training special skills in young children often involves pleasant interactions because of their importance for attention and storage. When material and play activities are presented with careful planning, young children can be directed to experiment with new skills in ways that take advantage of motivation and pleasure while playing. According to Wahyudi [5], playing is the key for children in developing skills in terms of movement, especially moving in the water. The kinds of carried out games are in the form of running competitions aimed to train courage and speed while in the water. The water cats and fish game aims to foster cooperation in protecting the weak. The taking coins game aims to be brave so that you can dive and practice breathing in the pool. The expels poison game aims to be able to deal with bursts of water that hit the face and get used to opening the eyes even though the eyes are splashed by water. Then, blowing an object game aims to water adjustment and control breathing. The diving game aims to regulate breathing, while the pulling the buoy game aims to train swimming skills and body awareness. All games are adjusted according to the aspects to be assessed.

\section{Conclusion}

The results showed that there were three swimming skill categories, including good category (six children with a percentage of forty-six point fifteen), moderate category (four children with a percentage of thirty point seven six), and less category (three children with a percentage of twenty-three point zero seven). Thus, aquatic exercise with the play method can improve swimming skills in preschool children. Suggestions for further research is to use other experimental methods, with a large sample, and increase the number of meetings.

\section{Acknowledgement}

I would like to thank the parties involved in this research, especially the coaches, pre-schoolers, and their parents who are members of the Arhesa Swimming Club for their permission, assistance, and encouragement in the preparation of this article. I would also like to thank the family who are always there and continue to provide encouragement and enthusiasm that motivates me to complete this research.

\section{REFERENCES}

[1] Susanto, E. (2010). Pengembangan tes keterampilan renang anak usia prasekolah. Jurnal Penelitian Dan Evaluasi Pendidkan, 2, 1-24.

[2] Diamond, E. F. (1975). Swimming instruction for pre-school children. The Journal of Sports Medicine, 3(2), 58-60. https://doi.org/10.1177/036354657500300202

[3] Erbaugh, S. J. (1986). Effects of aquatic training on swimming skill development of preschool children. Perceptual and Motor Skills, 62(2), 439-446. https://doi.org/10.2466/pms.1986.62.2.439

[4] Nah, K. O., \& Waller, T. (2015). Outdoor play in preschools in England and South Korea: learning from polyvocal methods. Early Child Development and Care, 185(11-12), 2010-2025. https://doi.org/10.1080/03004430.2015.10283 97

[5] Wahyudi, U. (2007). Pendekatan bermain dalam meningkatkan keterampilan mengapung. Jurnal IPTEK Olahraga, 9(3), 182-190.

[6] Arhesa, S., Badriah, D. L., \& Mulyani, S. (2019). The effect of jigsaw cooperative learning model on students' result breaststroke skill at tenth grade social science of senior high school 3 Cirebon city. Journal Pf Physiology, Nutrition and Physical Education, 4(2), 437-439.

[7] Getz, M., Hutzler, Y., Vermeer, A., Yarom, Y., \& Unnithan, V. (2012). The Effect of Aquatic and Land-Based Training on the Metabolic Cost of Walking and Motor Performance in Children with Cerebral Palsy: A Pilot Study. ISRN Rehabilitation, 2012, 1-8. https://doi.org/10.5402/2012/65 7979

[8] Lim, H. S., \& Yoon, S. (2014). The influence of short-term aquatic training on obstacle crossing in gait by the elderly. Journal of Physical Therapy Science, 26(8), 1219-1222. https://doi.org/10.1589/jpts.26.1219

[9] Valtonen, A., Pöyhönen, T., Sipil, S., \& Heinonen, A. (2011). Maintenance of aquatic training-induced benefits on mobility and lower-extremity muscles among persons with unilateral knee replacement. Archives of Physical Medicine and Rehabilitation, 92(12), 1944-1950. https://doi.org/10.1016/j.apmr.2011.07.191

[10] Kargarfard, M., Etemadifar, M., Baker, P., Mehrabi, M., \& Hayatbakhsh, R. (2012). Effect of aquatic exercise training on fatigue and health-related quality of life in patients with multiple sclerosis. Archives of Physical Medicine and Rehabilitation, 93(10), 1701-1708.https://doi.org/10.1016/ j.apmr.2012.05.006

[11] Arhesa, S., \& Dkk. (2020). Identifikasi faktor-faktor 
penghambat belajar renang. Journal Respecs, 2(2), 10-17.

[12] Anista, Sivagnanam, \& Arumugam. (2018). Effect of aquatic training on agility and strength among preadolescence boys. Journal of Research and Analytical Reviews, 5(4), 184-187.

[13] Tsourlou, T., Benik, A., Dipla, K., Zafeiridis, A., \& Kellis, S. (2006). The effects of a twenty-four-week aquatic training program on muscular strength performance in healthy elderly women. Journal Strength And Conditioning Research, 20(4), 811-818.

[14] Pöyhönen, T., Sipilä, S., Keskinen, K. L., Hautala, A., Savolainen, J., \& Mälkiä, E. (2002). Effects of aquatic resistance training on neuromuscular performance in healthy women. Medicine and Science in Sports and Exercise, 34(12), 2103-2109. https://doi.org/10.1097/0000 5768-200212000-00036

[15] Katsura, Y., Yoshikawa, T., Ueda, S. Y., Usui, T., Sotobayashi, D., Nakao, H., Sakamoto, H., Okumoto, T., \& Fujimoto, S. (2010). Effects of aquatic exercise training using water-resistance equipment in elderly. European Journal of Applied Physiology, 108(5), 957-964. https://doi.org/10.1007/s00421-009-1306-0

[16] Colado, J. C., Garcia-Masso, X., Rogers, M. E., Tella, V., Benavent, J., \& Dantas, E. H. (2012). Effects of aquatic and dry land resistance training devices on body composition and physical capacity in postmenopausal women. Journal of Human Kinetics, 32(1), 185-195. https://doi.org/10.2478/v 10078-012-0035-3

[17] Vallejo, L., Pardo, A., Gomis, M., Gallach, J. E., Perez, S., \& Querol, F. (2010). Influence of aquatic training on the motor performance of patients with haemophilic arthropathy. Haemophilia, 16(1), 155-161. https://doi.org/ 10.1111/j.1365-2516.2009.02098.x

[18] Arazi, H., \& Asadi, A. (2011). The effect of aquatic and land plyometric training on strength, sprint, and balance in young basketball players. Journal of Human Sport and Exercise, 6(1), 101-111. https://doi.org/10.4100/jhse.2011. 61.12

[19] Engelhart, M. D., \& Aiken, L. R. (1975). Book Reviews : Book Reviews. In Educational and Psychological Measurement (Vol. 35, Issue 1). https://doi.org/10.1177/00 1316447503500129 